\title{
THE INFLUENCE OF PICTURE AND PICTURE MODEL ON INDONESIAN WRITING SKILLS
}

\author{
Linda Mulyani \\ Department of Primary School Teacher Education, Faculty of Teacher Training and Education, \\ Universitas Kuningan, Indonesia \\ E-mail: lindamulyani22@gmail.com
}

\begin{abstract}
Dadang Solihat
Department of English Education, Faculty of Teacher Training and Education, Universitas Kuningan, Indonesia

E-mail: dacu_qta@yahoo.co.id
\end{abstract}

Ifah Hanifah

Department of Indonesian Education, Faculty of Teacher Training and Education, Universitas

Kuningan, Indonesia

E-mail: hanifahifah@gmail.com

\begin{abstract}
APA Citation: Mulyani, L., Solihat, D., \& Hanifah, I. (2018). The influence of picture and picture model on Indonesian writing skills. Indonesian Journal of Learning and Instruction, 1(2), 33-38.
\end{abstract}

\begin{abstract}
This study aims at determining the effect of the use of picture and picture model on Indonesian writing skills narration essay in the class IV A and IV B Elemetary School 1 Purwawinangun. The samples in this study are 49 students. The method used in this research is quasi experiment. Data collection techniques used in this study is an essay written test. Data analysis technique in this research is normality test, homogeneity test, $t$-test, and n-gain test. The result of pretest mean score of experimental and control class are 44.2 and 43.6. The result of posttest mean score of experimental and control class are 82.8 and 72.4. The result of the hypothesis test obtained the value of based on the t-test results obtained 0,000 significance level, where $0.000<0.05$, it means that $\mathrm{Ha}$ accepted based on the acceptance criteria hypothesis and Ho rejected, that there is an effect of using Picture and Picture type cooperative model on narration essay writing skill of students. The result of the n-gain test is 0.7 indicating that there is an increase in the experimental group using the picture and picture type cooperative model with high criteria. So it can be concluded that there is influence of using of picture and picture type in cooperative model of students narration essay writing skills.
\end{abstract}

Keywords: cooperative model; picture; writing skill; narration essay.

\section{INTRODUCTION}

Indonesian Language Learning has a predetermined scope and goals which is including growing the ability to express thoughts and feelings through good and true language. According to Resmini (2008: 2), Indonesian language learning has the aim at inproving students' ability to communicate both speaking and writing, as well as the intended learning to improve students' ability in appreciating literary works.
Beside improving language skills, Indonesian language learning is also to improve thinking and reasoning skills, and to broaden horizons. Tarigan (2013: 1) said that in the communication process there are 4 different but interconnected, they are listening, speaking, reading, and writing. These four aspects need to get full attention in Indonesian language learning.

One aspect of language skills that has an important role in human life is writing skills. Tarigan (2013: 3) suggests that writing skills 


\section{Linda Mulyani, Dadang Solihat \& Ifah Hanifah}

The influence of picture and picture model on Indonesian writing skills

are the characteristic of educated people or educated nation. Teaching writing skills are given to Elementary School students with the aim that students are not only master the theory of writing but also the practice of writing. Writing skills are skills that are not automatically mastered by students, but they must go through practice and regular practice. The ability of a child in identifying, understanding, criticizing, and creating will be stimulated if he has high reading and writing motivation. Therefore, reading and writing can be said to be a basic ability that must be possessed by all students to build a comprehensive reading and writing ability. Mustofa (2008: 2) said that the process of reading and writing characterized by reading and writing demonstrations, interactive cooperation between parents / teachers and children, based on daily needs and in a minimal but direct teaching method (minimal direct) must be taught and applied early. The things taught are things that are close to the child's life. During this time, writing learning in Elementary Schools is more often presented in the form of writing theory rather than writing practice, so students only get their knowledge in writing.
Based on the results of a preliminary study at State Elementary School 1 Purwawinangun, there are still many students who are not actively involved in the learning process. Students are only passively listening to and accepting the subject matter, so writing learning becomes a monotonous and tedious activity for students. Such conditions are one of the obstacles for students to express their ideas and feelings in writing narrative essays. Another factor that inhibits students' narrative writing skills is, teachers have not been able to practice writing skills, lack of use of varied and interesting models and learning media that can assist them in the learning process.

The above is strengthened based on the results of a preliminary study on the score of the narrative essay writing skills of Grade IV State Elementary School 1 Purwawinangun students in Indonesian language subjects, which shows that there are still students who have not reached the predetermined minimum completeness criteria (KKM) of 70. The following is the data of student writing scores on Indonesian subjects:

Table 1. Data of students' score in narrative writings skill

\begin{tabular}{lccccc}
\hline Class & Student's & KKM $>70$ & Persentase & KKM $<70$ & Persentase \\
\hline IV A & 25 & 5 & $20 \%$ & 20 & $\mathbf{8 0 \%}$ \\
\hline IV B & 25 & 6 & $24 \%$ & 19 & $76 \%$ \\
\hline
\end{tabular}

Source : Elementary School 1 Purwawinangun

Based on the table above, it is known that the value of students' writing skills in Indonesian language subjects is still low. From 25 students in grade IV A, only 5 students $(20 \%)$ reached the KKM, while 20 other students $(80 \%)$ showed the value of students' narrative writing skills that were still less than the criteria. In class IV B, from 25 students only 6 students (24\%) reached the KKM, while 19 other students (76\%) showed the value of the students' narrative writing skills that were still less than the criteria. The lower score of narrative essay writing skills shows that students are less skilled in writing. This can be seen in the essays made by students which are very short, less skilled at composing sentences and not using the right choice of words, and the use of spelling and punctuation is not appropriate. More over It can be seen that students' learning motivation is low, because the learning provided by the teacher is monotonous, so students feel bored. Students are not actively involved and are not required to be creative to express their ideas.

However there is a need to find an innovation teacher in providing interesting learning and makes students able to receive, and understand the learning material provided by the teacher in the teaching and learning process, one of which is in the 
narrative essay writing skills. One way to improve narrative essay writing skills is to use cooperative learning models.

Cooperative learning is a student learning activity carried out by grouping. Group learning model is a series of learning activities carried out by students in certain groups to achieve the learning objectives that have been formulated (Sanjaya, 2010: 46). In cooperative learning, the teacher acts more as a facilitator which serves as a bridge to a higher understanding, with the student's own notes. Teachers not only provide knowledge to students, but also must build knowledge in their minds. Students have the opportunity to gain hands-on experience and apply their ideas, this is an opportunity for students to find and apply their own ideas (Rusman, 2014: 202).

Ideally the teacher must be able to hold a variety of interesting learning models and can generate high learning motivation. One alternative learning model that can be used is the cooperative model type picture and picture. Suprijono (2011: 125) says that picture and picture are strategies or ways of learning that use images as learning media. In this model, the images given to students must be paired or logically sorted. This model will be more optimal with the media support used, namely the image media. Reasons for using cooperative learning model type picture and picture because this model has many advantages. Kurniasih and Berlin (2016: 45) said that the advantages of cooperative learning model type picture and picture are as follows:

1) The teacher can easily know the abilities of each student.

2) Train students to think logically and systematically.

3) Helping students learn to think based on the point of view of a subject the discussion by giving students freedom argues against the images shown.

4) Can lead to student learning motivation towards a better direction.

5) Students are involved in classroom planning and management.
Based on the above problems, it is necessary to improve the Indonesian language subject in class IV Elementary School 1 Purwawinangun to improve the skills of students' narrative essay writing on Indonesian subjects. So the writer examines this matter by carrying out a research entitled "The Effect of Using Picture and Picture Cooperative Models on Writing Narrative Skills of Students in Class IV Elementary School 1 Purwawinangun.

\section{METHOD}

The research method used in this study is an experimental method with a quantitative approach. According to Sugiyono (2016: 107) the experimental research method was a research method used to find out the influence of certain treatments on others under controlled conditions. The type of experimental research method used was a quasi experimental design research method. Sugiyono (2016: 114) said that quasi experimental design research was a development of true experimental design, which is difficult to implement. This design had a control group, but could not fully function to control external variables that affect the implementation of the experiment. The quasi experimental design used in this study was the Nonequivalent Control Group Design. According to Sugiyono (2016: 79) this design consists of two groups that were not chosen randomly. The design of this study had two selected groups, namely the experimental group and the control group. In this design, the test was conducted twice, namely pretest and posttest. Preliminary tests (pretest) were carried out before being given treatment in the experimental class, after which the treatment was given, and then given a posttest. Just like the experimental class, the control class was given a pretest first, but the learning was not given treatment, and then given a posttest. According to Sugiyono (2016: 116) this design could be described as follows: 


\section{Linda Mulyani, Dadang Solihat \& Ifah Hanifah}

The influence of picture and picture model on Indonesian writing skills

Table 2. Nonequivalent control groups pretest-posttest design

\begin{tabular}{cccc}
\hline Class & Pretest & Treatment & Posttest \\
\hline Experimental & $\mathrm{O}_{1}$ & $\mathrm{X}$ & $\mathrm{O}_{2}$ \\
Control & $\mathrm{O}_{3}$ & & $\mathrm{O}_{4}$ \\
\hline
\end{tabular}

Remarks:

O1: Pretest experimental group

O2: Posttest of the experimental group

O3: Pretest control group

O4: Posttest of the control group

$\mathrm{X}$ : Treatment

According to Arikunto (2013: 160) research instruments were facilities used by researchers in collecting data so that their work was easier and the results were better, in the sense that they were more accurate, complete, and systematic so that they are easily processed. This study used a research instrument in the form of a test rubric for writing narrative essays. There were five aspects that were used as the focus of the assessment of the narrative essay writing contained in the table below.

Table 3. Guidelines for assessing writing tests for narrative writings

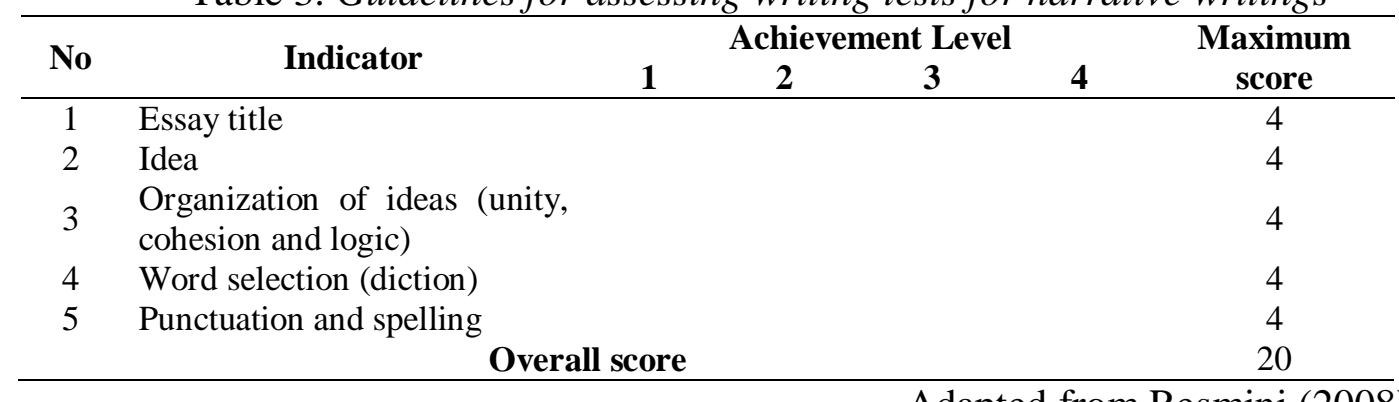

\section{RESULTS AND DISCUSSION}

Learning activities used cooperative learning type picture and picture were highly recommended to be applied to learning activities in Elementary School. Activities carried out through this model can train students to think logically and systematically. Differences in the results of students' narrative writing skills in Indonesian subjects, between classes that received treatment using the Picture and Picture type cooperative model with classes that did not receive treatment using the Picture and Picture type cooperative model, were one of the aspects examined in the learning process. The posttest resulted between the experimental class and the control class were tested by using the t-test to determine whether or not there was an influence of the use of the Picture and Picture type cooperative model on the narrative essay writing skills of students in grade IV of SD Negeri 1 Purwawinangun. As for the results of the T-Test which showed a significance value of 0.000 which was smaller than 0.05 , so that $\mathrm{Ha}$ was accepted based on the hypothesis acceptance criteria and $\mathrm{H} 0$ was rejected. Thus, it could be concluded that there were differences in the results of narrative essay writing skills between experimental class students and control class students.

The data on the differences in the results of the skill of writing narrative essays for students with KKM scores for the experimental class and control class were as follows: 
Table 4. Differences in the results of students' narrative writing skills in experimental classes and control classes

\begin{tabular}{cccccc}
\hline Group & Test & $\begin{array}{c}\text { The } \\
\text { Number } \\
\text { of } \\
\text { Students }\end{array}$ & \multicolumn{2}{c}{$\begin{array}{c}\text { Minimum Completion } \\
\text { Criteria }\end{array}$} & $\begin{array}{c}\text { Graduation } \\
\text { Percentage }\end{array}$ \\
& & Complete & Incomplete & \\
Experimental & Pretest & 25 student & - & 25 & $0 \%$ \\
\cline { 3 - 5 } Control & Posttest & 25 student & 25 & - & $100 \%$ \\
& Pretest & 25 student & - & 25 & $0 \%$ \\
& Posttest & 25 student & 18 & 7 & $72 \%$ \\
\hline
\end{tabular}

Based on the table above, it could be seen that students who had reached the $\mathrm{KKM}$ for the posttest in the experimental class are $100 \%$. Meanwhile, those who met the KKM for the posttest in the control class are $72 \%$. This study assessed the differences in the results of the students' narrative essay writing skills from the grades obtained. The results of the students' narrative essay writing skills between the experimental class and the control class were different, it could be seen from the results of the narrative essay writing skills that the experimental class students were better than the control class. It could also be seen from the results of narrative essay writing skills in class IV A (experiment) shown the average value of pretest was 44.2 and the posttest value was 82.8, while in class IV B (control) the average pretest score is 43.6 and posttest value of 72.4. The results of obtaining these data can prove that there was an effect of using the Picture and Picture type cooperative model on students' narrative essay writing skills in grade IV of SD Negeri 1 Purwawinangun. Based on the results of data analysis obtained from the $\mathrm{N}$-gain value in the experimental class of 0.70 which was presented in the $\mathrm{N}$-gain criteria, in the learning process used the Picture and Picture type cooperative model was high, while the control class was 0.51 which was preset in the $\mathrm{N}$-gain value was classified as medium. It could be concluded that there was a difference in the gain between the experimental classes in the learning process used the Picture and Picture type cooperative model, with the control class in the learning process used conventional methods.
The achievement of learning competence showed that the use of cooperative learning type picture and picture in learning could improve narrative essay writing skills. Through cooperative learning type picture and picture students were trained to think logically and systematically. This was reinforced by the opinion of Huda (2011:) who said that one of the advantages of the cooperative model type picture and picture was that the teacher was more aware of the ability of each student, students are trained to think logically and systematically, students were helped to learn to think based on the point of view of a subject with giving students freedom in the practice of thinking, students' motivation to learn was increasingly developed, students were involved in classroom planning and management.

Thus it could be seen that the learning process that used a cooperative model type picture and picture would affect the results of students' narrative essay writing skills. This was because this model could provide a pretty good influence on students' narrative writing skills. In the use of this model also in the learning process was able to make students become more active and work together to paste or compose images, able to express ideas, and explored and builded their abilities independently.

\section{CONCLUSION}

Based on the results of the research that has been carried out in the IV State Elemenary Schooli 1 Purwawinangun, on the subject of Writing Narrative Essays, Indonesian Language subjects concluded that: 


\section{Linda Mulyani, Dadang Solihat \& Ifah Hanifah}

The influence of picture and picture model on Indonesian writing skills

There is an effect of using the Picture and Picture type cooperative model on the narrative essay writing skills of students in grade IV SD Negeri 1 Purwawinangun. This is proven based on the results of the t-test obtained a significance level of 0.000 , where $0.000<0.05$, then $\mathrm{Ha}$ is accepted based on the acceptance criteria of the hypothesis and Ho is rejected, that there is an effect of using the Picture and Picture type cooperative model on students' narrative essay writing skills. There is a difference in the increase (gain) of the results of the skill of narrative essay writing between experimental classes using the Picture and Picture type cooperative model with the control class that uses conventional learning methods. Obtained the results of the calculation of the $\mathrm{N}$-gain test using independent sample t-test obtained the results of Sig $<0.05$. Thus the Sig. (2-tailed) obtained is $0,000<0,05$. Where the overall $\mathrm{N}$-gain in the experimental class gets a value of 0.7 (high), while the overall $\mathrm{N}$-gain in the control class gets a value of 0.5 (moderate). It can be concluded that there is a significant change / increase between the experimental class and the control class.

\section{REFERENCES}

Arifin, Z. (2011). Learning evaluation. Bandung: PT Remaja Rosdakarya.

Arikunto, S. (2013). Research procedure. A practice and approach. Jakarta: Rineka Cipta.
Hamdani. (2011). Learning strategy. Jakarta: Pustaka Setia.

Huda, M. (2013). Learning and instruction models. Yogyakarta: Pustaka Pelajar.

Istarani. (2011). Innovation learning models. Medan: Media Persada.

Keraf, G. (2010). Argumentation and narration. Jakarta: PT Gramedia Pustaka Utama.

Mustofa, B. (2008). From early literation to technology literation. Bandung: Center of Research on Education and Sociocultural Transformation.

Resmini, Djuanda, \& Indihadi. (2008). The development of Indonesian language instruction. Bandung: UPI PRESS.

Riduwan. (2013). An easy research. Bandung: Alfabeta.

Rusman. (2014). Learning models. Jakarta: PT Raja Grafindo Persada.

Sanjaya, W. (2010). Strategy of learning in education standard orientation. Jakarta: Kencana Peranada Media.

Sugiyono. (2016). Quantitative, qualitative, and research development methods. Bandung: Alfabeta.

Supardi. (2017). Statistic for education research. Depok: Rajawali Pers.

Suparno dan Yunus. (2010). The basic of writing. Jakarta: Universitas Terbuka.

Suprijono, A. (2011). Cooperative learning (theory and application PAIKEM). Yogyakarta: Pustaka Pelajar.

Tarigan. (2013). Writing as a language skill. Bandung: Angkasa. 